\title{
Use of Scientific-Artistic and Substantive Reconstruction in the Process of Studying Military Arts of Ancient and Medieval Nomads of South Siberia and Central Asia
}

\author{
Julius S. Khudiakov* \\ Institute of Archaeology and Ethnography SB RAS \\ 17 Akademika Lavrentieva Pr., Novosibirsk, 630090, Russia
}

Received 11.12.2014, received in revised form 20.02.2015, accepted 11.03.2015

The paper analyzes the experience of creation and use of scientific-artistic and substantive reconstructions of the weapon systems of ancient and medieval nomadic peoples who inhabited the mountains and steppes of South Siberia and Central Asia for scientific purposes. The main results of the previous experiments held by the researchers in classification of ancient and medieval weapon objects of Eurasia steppe zone's ancient and medieval peoples are manifested. The basic principles of formal signs typological classification of the subjects of offensive and defensive weapons' objects from the archaeological sites and collections from the monuments of the nomadic cultures of Central Asia historical and cultural region are reviewed. As a result of the ancient or medieval nomadic population armaments classification analysis, it is possible to identify the spectrum of kinds and typological diversity of weapons as a part of object complex of each specific archaeological culture. All the variety of the specific archaeological culture's classified forms of weapon can be consolidated to a single set of the implements of war. On the basis of the identified set, it is possible to carry out scientific-artistic reconstructions of the nomad warriors' look. These pictures of ancient and medieval nomadic warriors could be used as a model for making substantive reconstructions containing items of offensive and defensive weapons made of modern materials. Such objects can be used for identification of functional characteristics of various objects and their details as a part of weapons complex. Substantive reconstructions can be valuable teaching aids for delivering lectures or conducting seminars on military history of the nomadic peoples of Central Asia historical and cultural region, during the training process.

Keywords: South Siberia, Central Asia, scientific-artistic and substantive reconstructions, weapon systems, ancient and medieval nomads.

The paper is written within the frames of project "Study of the Art of War of Ancient and Medieval Peoples of South Siberia and Central Asia".

Research area: history.

Among different types of material resources relating to the substantive complex of ancient and medieval archaeological cultures of North and Central Asia, such class of objects as weapons occupies an important place. Weapons, obtained during excavations or collections at the archaeological sites of different cultures, provide valuable historical information about

(C) Siberian Federal University. All rights reserved

* Corresponding author E-mail address: khudjakov@mail.ru 
different spheres of ancient and medieval ethnic groups' life, including the level of development of military science, metallurgy, metalwork and other types of material production, trade and cultural contacts, social stratification of society and some features of their spiritual culture. An important indicator of a certain class of objects' level of development is a degree of their differentiation and forms specialization - specific and typological diversity. Among objects relating to different types of activities, weapon is the most functionally deterministic compared to the other complexes, as lives of those individuals who used these weapon objects during military clashes directly depended on correlation of weapon object's shape to its functional purpose. At the same time all the weapon is divided to two functionally opposing types of substantive complexes - to the means of offense and defense. In turn, offensive weapons are also divided into two groups according to the distance from which stunning shocks are delivered - ranged weapon and short-range weapon. A range of means of destruction in ranged battle and close-range battle, combined with the means of protection make up a complex of weapon system of the warriors of ancient or medieval culture (Khudiakov, 1990. P. 7). Previous experience of armaments typological analysis demonstrated that identification of armaments typology units should be carried out on the basis of functional significance of its formal features. Recording and identification of other formal features, not directly related to the main function of the analyzed weapon object, for example, details of decoration, should be conducted separately from the main classification scheme. The task of formal typological analysis of armaments includes identification of functionally significant formal elements among them, their description in terms of formal definitions and establishing correspondence between them (Khudiakov, 1979.
P. 184). In previous decades the study of weapons of ancient and medieval peoples of Eastern Europe in national archaeological science and weapons research, scientists proposed various approaches to armaments classification from different complexes of ancient and medieval archaeological cultures. The researchers, who studied weapons of the Scythian and Sarmatians as well as warriors of medieval Russia, offered to take into account a variety of formal features for different types of weapons.

In the process of the Savromats' bladed weapons classification, K.F. Smirnov, who based upon prior researches of the Scythians' military art, took pommel and bayonet swords' parts and types as the basis for classification (Smirnov, 1961. P. 9). In the process of Savromats' arrowheads formal characteristics identification he marked other signs characteristics: a way of adjustment, crosssection and the shape of fletching (Smirnov, 1961. P. 37). In the 1980s V.A. Ivanov based his research on this study when characterizing armament of the ancient population of the Cisurals (Ivanov, 1984. P. 7, 12). Characterizing the bladed weapons, Russian soldiers used in the Early and High Middle Ages, A.N. Kirpichnikov, on the basis of previous studies of European swords by J. Petersen, divided all the findings of two-edged blades in the territory of Eastern Europe into several types according to the form of cross and pommel (Kirpichnikov, 1966a. Pp. 19-20, 26-37). The similar principle of bladed weapons classification on the basis of handle form is common in some foreign studies (Oakeshott, 2004. P. 126; Fig. 41). On the basis of this methodology he classified swords and shortbladed weapons (Kirpichnikov, 1966a. P. 68-70). At the same time he subdivided fond spearheads on the basis of different principle: on types according to the shape of fletching, and battleaxes into groups and types according to the size and blade shape (Kirpichnikov, 1966b. Pp. 6, 9, 
12-17, 29, 33-, 35-40). The most significant for the classification analysis of the medieval Old Russian weapons was the experience of Old Russian iron arrowheads classification on the basis of such formal features as a way of adjustment, crosssection and the shape of fletching, proposed by A.F. Medvedev (Medvedev, 1966. Pp. 5455). Analyzing the Sarmatians' weapons, A.M. Khazanov divided bladed weapons, swords and daggers to groups according to such a feature as presence of ring pommel or its absence. Five types were identified according to cross, handle materials or lock among the swords and daggers without pommels. The researcher identified several types of iron three flange and bone arrowheads according to the shape of fletching and shoulders. Several types of spearheads were identified according to the shape of fletching and bushing (Khazanov, 1971. Pp. 9-10, 17, 36-37, 41, 46-48). In a research by E.V. Chernenko, devoted to Scythian archers, characterizing arrows from the Northern Black Sea region, the author paid considerable attention to the description of shafts, but didn't classify heads (Chernenko, 1981. Pp. 22-28). In the early 1970s, based on the analysis of the Yenisei Kyrgyz armaments materials, taking into account previous researches of Russian archaeologists - weaponologists, the author of this paper developed the basic principles of weapons' typological classification on the basis of the functional principles' functional significance. Among the objects of offensive weapons working units for inflicting damaging blows or for protection from them, and load bearing element adapted to bring them into action or connect the working units, were identified. Cross-section as well as shape or linear outline were identified as the most significant features of working units of the offensive weapons' objects. Particular features of shielded armor's protective coating and combat helmets can be distinguished as a part of functionally important working units of personal metal means of protection (Khudiakov, 1979. P. 184-192). Researches, devoted to the study of the weapon systems of ancient and medieval peoples of the Ancient East, the Volga region, the Urals, South Siberia, Kazakhstan and Central Asia successfully continue for decades until today (Khudiakov, 1986; Khudiakov, 1991; Gorelik, 1993; Gorelik, 2002; Gorbunov, 2003; Gorbunov, 2006; Izmailov, 2000; Kocheev, 1999; Plotnokov, 1990; Allaniiazov, 1996; Allaniiazov, 1998; Kushkumbaev, 2001; Bobrov, Khudiakov, 2008).

As bladed weapons were used during a long historical period and it was used until the modern period of the world history, a lot of important informative evidence about the purpose and use of different types of armament were preserved in written historical, pictorial and other historical sources. Using this information and materials to determine functional purpose of different kinds and types of weapons is a necessary part of weapons research. All the classical works on military history are based upon the analysis of written historical and pictorial sources data (Boeheim, 1995. P. 130; Winkler, 1992. Pp. 254255; Markov, 2007. Pp. 21-32, 387-410; Razin, 1955. Pp 74-81, 109). Ancient and medieval pictorial sources, elaborated in a realistic depiction manner became the basis for illustrating these works by the modern artists. However, as a rule, findings of armaments from the ancient and medieval cultures' archaeological monuments excavations were not taken into account.

The results of weapons study and reconstruction of the weapons system could be used to assess a particular ethnic group and a state's level of military art development during a certain historical period, to determine the composition of forces and service arms, to supplement the written historical sources of information about the features of the art of war. In addition to the use of armaments findings for the 
military history study, it can serve as a valuable informative source to solve some other problems of historical research. Due to considerable variability of certain types of weapons of massproduction, such as arrowheads, such objects can be an important chronological indicator for a monument, with which they were found. These findings are of particular importance for those archaeological sites where other common forms of things are absent. Not as often as arrows, but some kinds and types of weapons can be used to characterize the whole object complex of a particular culture. Armament supplies made of metal are an important source for study and evaluation of metallurgy and metalwork's level of development. As a rule, for most of the cultures of North and Central Asia, arms production was the most developed area of metallurgical production. In some cultures expensive ceremonial weapons were objects of trade, payment of tribute, or were used as diplomatic gifts. Presence of some expensive for its time weapon types as a part of accompanying inventory in the graves of some ancient and medieval cultures in Central Asian historical and cultural region could be a sign of high social status of the owner and social stratification of society. Various variants of weapons placement in graves provide some criteria that characterize religious beliefs in society. An important indicator of the relationship to arms might be cases of ritual weapon damage or replacement of real weapon by votive copies. Weapons were often objects of decoration and were depicted on the objects of ancient and medieval art. Due to engravings and abbreviations on armaments, weapons could be a valuable epigraphic source.

Carried out classification analysis allows us to identify the diversity of weapons types used by warriors of an ancient or medieval ethnic group, a carrier of specific archaeological or traditional ethnographic culture. Consolidation of all the selected forms and types of offensive and defensive weapons to a single complex of armaments should be a definite result of weapons study, devoted to the analysis of an individual culture.

Weapon systems of specific nomadic cultures, developed on the basis of the classification analysis are methodological basis for creation of scientific and artistic reconstructions of the external appearance of Central Asia historical and cultural region ancient and medieval peoples' warriors. Proposals to reconstruct the details of ancient and medieval nomads' weapons and the art of war of the entire historical and cultural region or its individual areas are possible on the basis of already studied weapons complexes of the main ethnic groups that live in their territories (Khudiakov, 1986. Pp. 207-225). For the proper reconstruction of the weapons of war it is necessary to appeal to the findings of armaments from the excavations of the studied nomadic culture sites, images of soldiers and weapons on the monuments of the fine, monumental and decorative art, as well as information from the written historical sources about the art of war of the nomadic ethnic groups and cultures, which sets of weapons is it planned to study. To ensure authenticity of the proposed reconstruction of the a separate culture' weapons complex it is necessary to relate the obtained results with analogies of the main weapons types from sites of the other synchronous cultures, which bearers belong to the same cultural and economic type as the ethnic group under study. Well-preserved samples of such weapons in the cultures of ethnic groups with closely related and similar culture can be specimen for the weapons reconstruction validity.

In the history of modern Russian weaponology there were cases then different researchers proposed various options for defensive weapons reconstruction based on the same archaeological materials. For example, based on the findings of iron-clad plates that were a part 
of the treasure or tribute inside the caldron found in the outskirts of the town of Abaza in the south of Khakassia, different options for the protective cover reconstruction were offered (Sunchugashev, 1979. Pp. 133-134). The author of this paper, based on the quantity proportion of plates of different shapes and sizes proposed reconstruction of the Abaza armor in the form of coat-of-plates kuyak that had protective cover in the form of neck-piece, breastplate, sleeves and hem. Such a reconstruction corresponded with the size and number of plates that covered different, the most vulnerable part of the warrior's body (Khudiakov, 1980. Pp. 123-124; Table. XLIII). Another variant of the Abaza armor reconstruction in the form of shell - robe with neck-pieces, chest and back cover was later proposed by M.V. Gorelik in his work on early Mongolian armor (Gorelik, 1987. P. 184). The question of the validity of a particular reconstruction was resolved in practice. In this case, an important criterion in favor of the graphic reconstructions authenticity was the subject copy of coat-of-plates made on the model of the Abaza amour - kuyak, previously graphically restored by the author of this paper (Khudiakov, 1980. Tabl. XLIII). Such a copy was made of modern materials in the form of an "internal" armor-kuyak and repeatedly tested for self-dressing, wearing and use during exhibitions and role-playing games by the members of military historical club "Mergen" in Abakan (Petrenko, Petrenko, 2004. Pp. 102-103). A lack of the necessary skills and experience in reconstruction of personal metal protection means can lead to creation of erroneous graphic and even object copies of ancient and medieval coat of mails and armor. As an example it is possible to provide an unsuccessful graphic reconstruction of the ancient Turkic helmet with mail aventail proposed by G.V. Kubarev in 2002. A rectangular plate, about $15 \mathrm{~cm}$ long with a rounded edge and four pairs of holes along the long sides, two pairs from the lower edge and five along the central axis was used as a detail of the helmet's dome. On the rounded upper edge two holes were made perpendicular to it (Kubarev, 2002. Fig. 10, 8, 9; 11, 2, 3). V.D. Kubarev joined this variant of reconstruction (Kubarev, Kubarev, 2003. P. 73). According to the study, proposed by Vladimir Gorbunov, this reconstruction could be referred to the ovoid type of helmet with a flattened pommel, which crown was supposed to consist of 23 strip plates (Gorbunov, 2003. P. 67; Fig. 44, 45). Archaeologists of Altai State University succeeded in making a substantive reconstruction of such a helmet, despite the fact that plates in the upper part of the dome partially overlapped. However, neither the size nor the configuration of the upper edge or the holes location of the plate could be referred to helmet's crown. Holes location on it is similar to the holes on the other plates of the lamellar armor (Kubarev, 2002. Fig. 10, 1-3). Rounded upper edge clearly shows that this part of the plate should have been placed above the similar plates from the lamellar armor, but not be attached to the pommel, as the authors of this reconstruction believe. According to the previous experience of lamellar and scaly armor's substantive reconstructions, rounded edges of plates, connected to the horizontal rows were always placed one above another, partially overlapped row of plates. The rounding was done in order a warrior who put on the armor didn't' hurt himself and didn't tear his clothes on the plates' sharp edges. The plates from the helmet's dome, with the exception of lining plates should have sector-shaped form, as they should converge from the base to the pommel. Oval plate with a spherical protrusion at the center could not be helmet's pommel, since it does not conform to the shape of the dome. Most likely it could serve as a shield boss, that was attached to the chest part of the combined armor found in this ancient Turkic burial (Khudiakov, Bobrov, Philippovich, 2005. P. 96-97). 


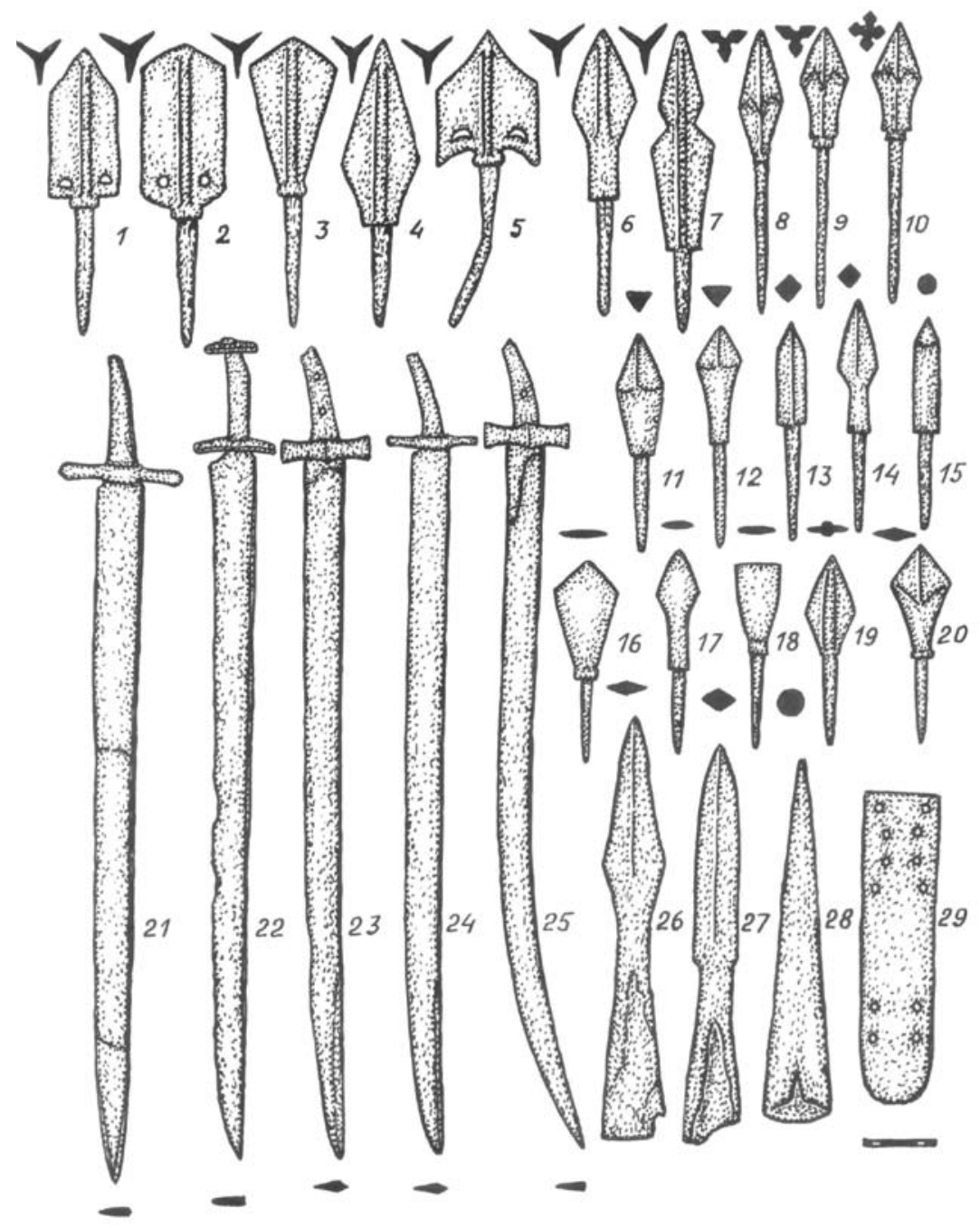

Fig. 1. Weapon System of Yenisei Kyrgyz Warriors of the $9^{\text {th }}-10^{\text {th }}$ Centuries

Weapon system development is the first and the most important step in making scientificartistic reconstruction. After creating such a complex, it is necessary to use graphic materials and written historical sources on military affairs of the studied ethnic group, which will help to make scientific and artistic reconstruction on the basis of different types of sources. As an example it is possible to offer reconstruction experience of the Kyrgyz soldier weapon complex dated by the era of "Kyrgyz Great Power" from the culture of the $9-10^{\text {th }}$ centuries' Yenisei Kyrgyz archaeological monuments, studied by archaeologists in the territories of Sayan Altai, Mongolia and East Turkestan (Khudiakov, 1980. Pp. 134-135). This complex consisted of compound bows with median side and medial frontal bone plates. Kyrgyz archers in this period were equipped with the broadest range of arrows with iron tips. They had threeblade tipped arrows with elongated pentagonal, elongated hexagonal, asymmetrically rhombic, elongated rhombic heads of tiered forms and tomars; two-bladed arrows with elongated rhombic form; flat arrows with asymmetricallyrhombic head, oval-winged form and tomars in 


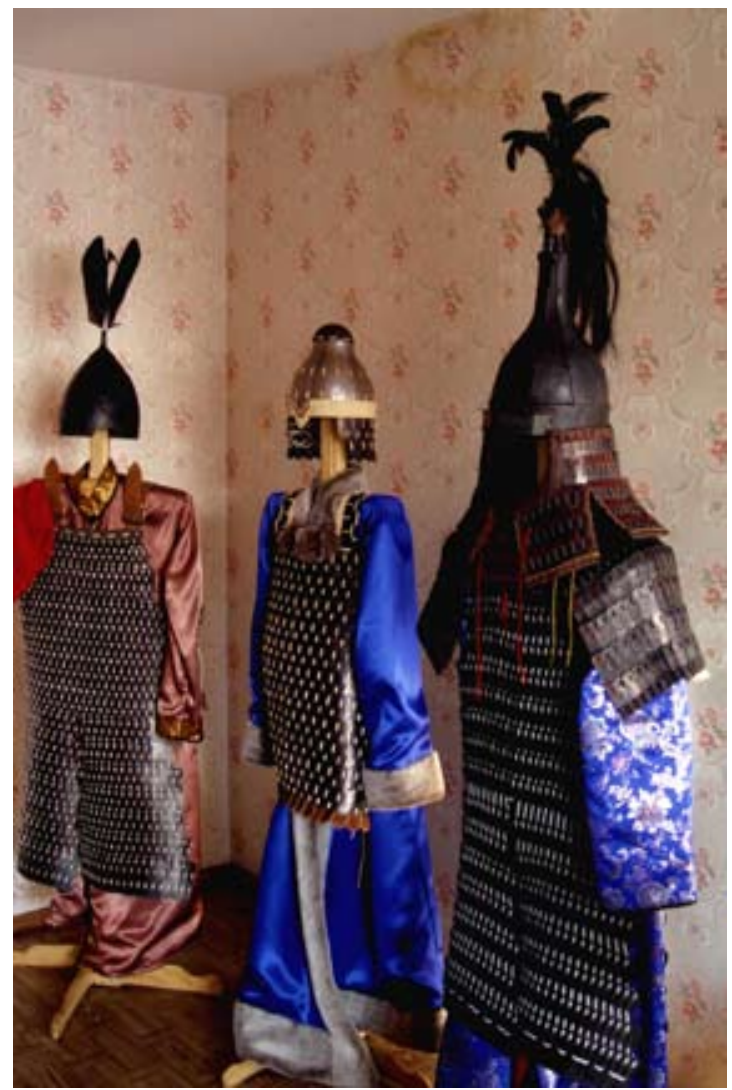

Fig. 2. Substantive Reconstructions of Syanbi, Old Turkic and Jurchen Warriors'Armors

their possession. All these arrows were aimed to defeat the enemy, protected by metal armor. In this period Kyrgyz archers were armed with multi-purpose arrows with flattened rhombic heads of asymmetrically-rhombic shape. They had especially broad spectrum of armor-piercing arrows of different shapes and triangular-threebladed, quadrangular-four-bladed, triangular, quadrangular and circular cross-section (Khudiakov, 1980. Pp. 79-100) (Fig. 1, 1-20). In close combat Kyrgyz armored horsemen could attack the enemy by ramming attacks using spears with flattened rhombic, quadrangular and round in cross-section heads as well as backswords and sabers with straight and slightly curved blades (Khudiakov, 1980. Pp. 34-44, 52-57) (Fig. 1, 21-28). For protection Kyrgyz horsemen used scaly and lamellar armor made of iron plates of rectangular shape with rounded edges and strap holes (Khudiakov, 1980. Pp. 119-123) (Fig. 1, 29). According to the images from the Sulek cave paintings, the images on the Kum Tur murals and bronze plaques from the Minusinsk basin, Kyrgyz warriors were armed with helmets of sphero-conical shape and rounded shields (Khudiakov, 1980. Tabl . L, 3; LI; LII).

All of these materials allow restoring the appearance of heavily armed Kyrgyz rider of the 9-10 ${ }^{\text {th }}$ centuries (Khudiakov, 1980. Tabl. XLVI) (Fig. 2).

The accumulated experience of creating scientific and artistic reconstructions makes it possible to restore sets of weapons and military equipment of even those ancient and medieval nomadic cultures of Central Asia historical and cultural region, among the culture remains of 


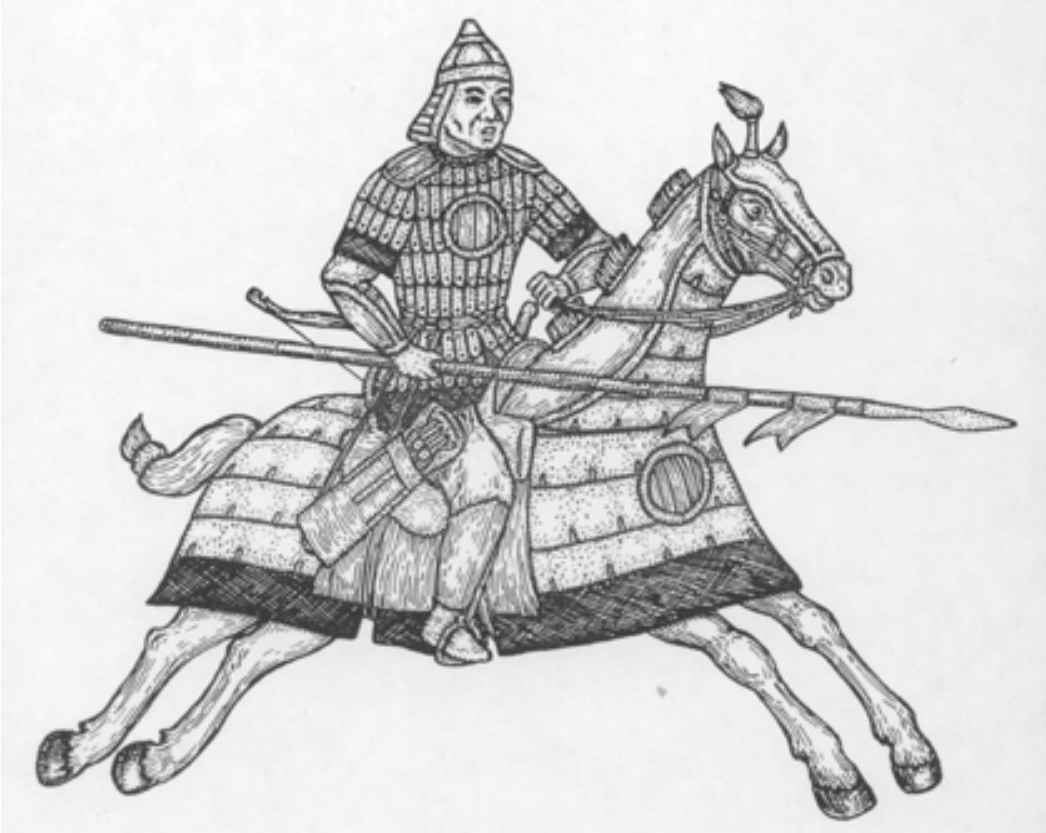

Fig. 3. Scientific-Artistic Reconstruction of the Kyrgyz Armor-Clad Rider of the $9^{\text {th }}-10^{\text {th }}$ Centuries

which there is no informative visual materials and no data from the written historical sources. In these cases, studies of scientific and artistic reconstructions of warriors' appearance of related in ethno-cultural respect cultures belonging to the same cultural and economic type could be taken as a historical basis. However, the degree of hypothetical character of reconstructions in these cases will be significantly higher.

It is possible to create subject copies of personal metal protection of warriors from different ancient and medieval cultures on the basis of scientific and artistic reconstructions. During the last decades in different Russian and some CIS countries' scientific centers mostly enthusiasts and fans of role-playing games were engaged in ancient and medieval armor manufacturing, made of modern materials. However, in several cities, professionals - military historians, weaponologists and blacksmiths were engaged in the subject copies production. A group of professionals accumulated quite successful and rich experience in scenery production on "Mosfilm" film studio, they made objects of weapons and armor for some museum exhibitions on the basis of scientific and artistic reconstructions by M.V. Gorelik (Abramzon, Gorelik, 1983. Pp. 238-244; Gorelik, 1983. P. 230258). They created substantive reconstructions of the Russian and Horde warriors' weapon system who took part in this historic battle for the militaryhistorical and natural reserve museum "Kulikovo Field" (Dvurechensky, 2008. Fig. 53). In the previous years at Novosibirsk State University, on the basis of fully preserved museum exhibits and scientific and artistic reconstructions, expert Y.A. Philippovich had made copies of Dzungar helmet and armor of the modern materials (Khudiakov, Bobrov, Philippovich, 2005. Pp. 97102). After that, based on scientific and artistic reconstructions and acquired skills, he made substantive reconstructions of Syanbi, Old Turkic and Jurchen armors (Fig. 3). Substantive reconstructions of combat helmets and armor made on the basis of such developments could serve as informative visual aids in the course of 
thematic lessons on history and culture of the nomadic peoples of Central Asia historical and cultural region during the training process.

The experience accumulated in the process of scientific-artistic and substantive reconstructions of the weapon system of ancient and medieval warriors identifies that their manufacture and use is essential for the study of the art of war and military history of the nomadic peoples of Central Asia and South Siberia.

\section{References}

1. Abramzon I.Y., Gorelik M.V. Nauchnaia rekonstruktsiia kompleksa vooruzheniia russkogo voina XIV v. i ego ispol'zovanie v museinikh ekspositsiyakh [Scientific Reconstruction of the $14^{\text {th }}$ Century Russian Warrior's Weapon System and Its Use in Museum Expositions] // The Battle of Kulikovo in History and Culture of Our Country. M.: Moscow University Publishing House, 1983. Pp. 238-244.

2. Allaniiazov T.K. Ocherki voennogo dela kochevnikov Kazakhstana [Essays on the Art of War of the Kazakh Nomads]. Almaty: Fond "21 vek", 1996. 94 p.

3. Allaniiazov T.K. Voennoe delo kochevnikov Kazakhstana [The Art of War of the Kazakh Nomads]. Almaty: Fond "21 vek", 1998. 140 p.

4. Boeheim W. Entsiklopediia oruzhiia [Encyclopedia of Weapons]. SPb.: Saint-Petersburg orkestr, 1995. $576 \mathrm{p}$.

5. Bobrov L.A., Khudiakov Y.S. Vooruzhenie i taktika kochevnokov Tsentral'noi Asii v epokhu pozdnego Srednevekov'ia i rannego Novogo vremeni (XV v. - pervaia polovina XVIII v.) [Weapons and Tactics of Central Asia Nomads in the Epoch of the Late Middle Ages and Early Modern Period (15 ${ }^{\text {th }}$ Century - the First Half of the $18^{\text {th }}$ Century)]. SPb.: SPbSU Phil. Dept. , 2008. $776 \mathrm{p}$.

6. Winkler von P.P. Oruzhie: rukovodstvo $k$ istorii, opisaniiu i izobrazheniiu ruchnogo oruzhiia s drevneishikh vremen do nachala XIXv. [Weapons: Guidance to History, Description and Depiction of Hand Weapons from the Ancient Times to the Early $19^{\text {th }}$ Century]. $2^{\text {nd }}$ edition. M., $1992.330 \mathrm{p}$.

7. Gorbunov V.V. Voennoe delo naseleniia Altaia vIII-XIVvv. Ch. I. Oboronitel'noe vooruzhenie (dospekh) [The Art of War of Altai Population in the $3^{\text {rd }}-14^{\text {th }}$ Centuries. Part 1. Defensive Weapon (Armor)]. Barnaul: Altai University Publishing House, 2003. 174 p.

8. Gorbunov V.V. Voennoe delo naseleniia Altaia v III-XIVvv. Ch II. Nastupatel'noe vooruzhenie (oruzhie) [The Art of War of Altai Population in the $3^{\text {rd }}-14^{\text {th }}$ Centuries. Part 2. Offensive Weapon (Armament)]. Barnaul: Altai University Publishing House, 2006. 232 p.

9. Gorelik M.V. Mongolo-tatarskoe oboronitel'noe vooruzhenie vtoroi poloviny XIV-nachala $X V v$. [Mongol-Tatar Defensive Weapons of the Second Half of the $14^{\text {th }}-$ Early $15^{\text {th }}$ Centuries] // The Battle of Kulikovo in History and Culture of Our Country. M.: Moscow University Publishing House, 1983. Pp. 244-269.

10. Gorelik M.V. Rannii mongol'skii dospekh (IXv. - pervaia polovina XIV v.) [Early Mongolian Armor $\left(9^{\text {th }}-\right.$ the First Half of the $14^{\text {th }}$ Centuries)] // Archaeology, Ethnography and Anthropology of Mongolia. Novosibirsk: Nauka, 1987. Pp. 163-208.

11. Gorelik M.V. Oruzhie Drevnego Vostoka (IV tysiacheletie do n. e. - IV v. do. n. e.) [Ancient Near East Weapons (the $1^{\text {st }}$ Millennium B.C. - the $4^{\text {th }}$ Century B.C.)]. M.: Nauka, 1993. 349 p. 
12. Gorelik M.V. Armii mongolo-tatar X-XIV vekov. Voinskoe iskusstvo, snariazhenie, oruzhie [Mongol-Tatar Armies of the $10^{\text {th }}-14^{\text {th }}$ Centuries. The Art of War, Equipment, Weapons]. M.: Vostochnii gorizont, 2002. $84 \mathrm{p}$.

13. Dvurechenskii O.V. Relikvii donskogo poboishcha. Nakhodki na Kulikovom pole [The Battle of Kulikovo Relics. The Kulikovo Field Findings]. M.: Kvadriga, 2008. 88 p.

14. Ivanonov V.A. Vooruzhenie $i$ voennoe delo finno-ugrov Priural'ia v epokhu rannego zheleza (I tys. do n. e. - pervaia polovina I tys. n. e.) [Weapon and the Art of War of Cisurals Finno-Ugrics in the Epoch of Early Iron Age (the $1^{\text {st }}$ Millennium B.C. - the First Half of the $1^{\text {st }}$ Millennium A.D.)]. M.: Nauka, 1984. 88 p.

15. Izmailov I.L. Vooruzhenie $i$ voennoe delo naseleniia Volzhskoi Bulgarii X-nachala XIII v. [Weapon and the Art of War of Volga Bulgaria Population of the $10^{\text {th }}-$ Early $13^{\text {th }}$ Centuries]. Kazan; Magadan: DVO RAS, 1997. 212 P.

16. Kirpichnikov A.N. Drevnerusskoe oruzhie [Old Russian Weapon. Iss. 1. Swords and Sables of the $9^{\text {th }}-13^{\text {th }}$ Centuries] // The Code of Archaeological Resources. M.; L.: Nauka, 1966a. Iss. E1-36. $179 \mathrm{p}$.

17. Kirpichnikov A.N. Drevnerusskoe oruzhie [Old Russian Weapon. Iss. 2. Spears, Lances, Battle-Axes, Maces and Chain Maces of the $9^{\text {th }}-13^{\text {th }}$ Centuries] // The Code of Archaeological Resources. M.; L.: Nauka, 1966b. Iss. E1-36. 215 P.

18. Kocheev V.A. Boevoe oruzhie pazyryktsev [Battle Weapon of the Pazyryk] // Altai Antiquities. News Bulletin of Laboratory of Archaeology. Gorno-Altaisk: GASU Publishing House, 1999. № 4. Pp. $74-82$.

19. Kubarev G.V. Dospekh drevnetiurkskogo znatnogo voina iz Balyk-Sooka [Armor of Old Turkic Noble Warrior from Balyk-Sook] // Materials on Military Archaeology of Altai and CrossBorder Regions. Barnaul: Altai University Publishing House, 2002. Pp. 88-112.

20. Kubarev G.V., Kubarev V.D. Pogrebenie znatnogo voina iz Balyk-Sooka (Tsentral'nii Altai) [Burial of Noble Warrior from Balyk-Sook (Central Altai)] // Archaeology, Ethnography and Anthropology of Eurasia. 2003. № 4.

21. Kushkumbaev A.K. Voennoe delo kazakhov v XVII - XVIII vekakh [The Art of War of the Kazakhs in the $17^{\text {th }}-18^{\text {th }}$ Centuries]. Almaty: "Daik-Press", 2001. $172 \mathrm{p}$.

22. Markov M.I. Istoriia konnitsy. Ot drevnei Gretsii do izobreteniia ognestrel'nogo oruzhiia [Horse Cavalry History. From Ancient Greece to Fire Weapon Invention]. M.: Kuchkovo pole; Giperboleia, 2007. Book 1. 466 p.

23. Medvedev A.F. Ruchnoe metatel'noe oruzhie (luk i strely, samostlel) VIII - XIV vv. [HandHeld Missile Weapon (Bow and Arrows, Crossbow) of the $8^{\text {th }}-14^{\text {th }}$ Centuries]. / The Code of Archaeological Resources. M.: Nauka, Iss. E 1-36. 183 P.

24. Oakeshott E. Arkheologia oruzhiia. Ot bronzovogo veka do epokhi Renessansa [The Archaeology of Weapons: Arms and Armour from Prehistory to the Age of Chivalry]. M.: ZAO Tsentrpoligraph, 2004. $398 \mathrm{p}$.

25. Petrenko A.L., Petrenko Y.A. Zashchitnye svoistva srednevekovykh pantsirei Iuga Sibiri $i$ Tsentral'noi Azii (po materialam eksperimenta) [Protective Properties of Medieval Armor of the South of Siberia and Central Asia (Based on the Experiment Material)] // The Art of War of the Peoples of Siberia and Central Asia. Novosibirsk: Novosibirsk State University, 2004. Iss. 1. Pp. 102-112.

$$
-667-
$$


26. Plotnikov Y.A. Srednevekovyi mech iz Vostochnogo Kazakhstana [Medieval Sword from Eastern Kazakhstan] // The Art of War of Ancient and Medieval Population of Northern and Central Asia. Novosibirsk: Institute of History, Philology and Philosophy of SO AS USSR, 1990. Pp. 150154.

27. Razin E.A. Istoriia voennogo iskusstva [Military Art History]. M.: Ministry of Defense of the USSR Publishing House, 1955. Vol. 1. 559 p.

28. Smirnov K.F. Vooruzhenie savromatov [Savromats' Armament] // Materials and Research on the USSR Archaeology. M.: AS USSR Publishing House, 1961. № 101. 162 p.

29. Sunchugashev Y.I. Drevdniaia matallurgiia Khakassii. Epokha zheleza [Ancient Metallurgy of Khakassia. The Iron Age]. Novosibirsk: Nauka, 1979. 192 p.

30. Khazanov A.M. Ocherki voennogo dela savromatov [Essays on the Savromats' Military Art]. M.: Nauka, 1971. 171 P.

31. Khudiakov Y.S. Osnovnye poniatiia oruzhievedeniia (po materialam vooruzheniia eniseiskikh kyrgyzov VI-XII vv. n. e.) [The Main Notions of Weapon Studies (Based on Materials of The Yenisei Kyrgyz Armament of the $6^{\text {th }}-12^{\text {th }}$ Centuries A.D.)] // News in Archaeology of Siberia and the Far East. Novosibirsk: Nauka, 1979. Pp. 184-193.

32. Khudiakov Y.S. Vooruzhenie eniseiskikh kyrgyzov VI-XII vv. [Armament of Yenisei Kyrgyzs of the $6^{\text {th }}-12^{\text {th }}$ Centuries]. Novosibirsk: Nauka, 1980. $176 \mathrm{p}$.

33. Khudiakov Y.S. Vooruzhenie srednevekovykh kochevnikov Iuzhnoi Sibiri i Tsentral'noi Azii [Armament of Medieval Nomads of South Siberia and Central Asia]. Novosibirsk: Nauka, 1986. $268 \mathrm{p}$.

34. Khudiakov Y.S. Vooruzhenie tsentral'no-aziatskikh kochevnikov vepokhu rannego i razvitogo srednevekov'ia [Armament of Central-Asian Nomads in the Epoch of Early and High Middle Ages]. Novosibirsk: Nauka, 1991. 189 p.

35. Khudiakov Y.S. Oruzhie kak istoricheskii istochnik [Weapon as a Historical Source] // The Art of War of Ancient and Medieval Population of Northern and Central Asia. Novosibirsk: Institute of History, Philology and Philosophy of SO AS USSR, 1990. Pp. 5-10.

36. Khudiakov Y.S., Bobrov L.A., Philippovich Y.A. Opyt eksperimental'noi rekonstruktsii i funktsional'nogo analiza zashchitnogo vooruzheniia voinov Tsentral'noi Azii epokhi pozdnego Srednevekov'ia [Experience of Experimental Reconstruction and Functional Analysis of Protective Weapon of Central Asia Warriors in the Late Middle Ages] // Bulletin of Novosibirsk State University. Ser. History, Philology. 2005. Vol. 4. Iss. 5. Archaeology and Ethnography. Pp. 95-103.

37. Chernenko E.V. Skifskie luchniki [Scythian Archers]. Kiev: Naukova Dumka, 1981. 168 p. 


\title{
Использование научно-художественных и предметных реконструкций в процессе изучения военного дела древних и средневековых номадов Южной Сибири и Центральной Азии
}

\author{
Ю.С. Худяков \\ Институт археологии и этнографии СО РАН \\ Россия, 630090, Новосибирск, пр. Лаврентьева, 17
}

В статье анализируются опыты создания и использования в исследовательских иелях научно-художественных и предметных реконструкиий комплексов вооружения древних и средневековых кочевых народов, населявших горы и степи Южной Сибири и Центральной Азии. Прослеживаются основные результаты предшествующих опытов исследователей по классифицированию предметов древнего и средневекового оружия древних и средневековых народов Степного пояса Евразии. Рассматриваются главные принщипы типологической классификации по формальным признакам предметов наступательного и защитного вооружения из археологических раскопок и сборов из памятников культур кочевников Центрально-Азиатского историко-культурного региона. $B$ результате проведенного классификационного анализа предметов вооружения древнего или средневекового кочевого населения возможно выявление спектра видового и типологического разнообразия форм оружия в составе предметного комплекса каждой конкретной археологической культуры. Все многообразие расклассифицированных форм оружия конкретной археологической культуры может быть сведено в единый комплекс боевых средств. На основе выявленных комплексов возможно создание научно-художественных реконструкиий внешнего облика воиновкочевников. Такие рисунки древних и средневековых кочевых воинов можно использовать в качестве образияа при создании предметных реконструкиий, содержащих предметь наступательного и защитного вооружения, изготовленные из современных материалов. Подобные изделия могут использоваться при выяснении функииональных особенностей тех или иных предметов и их деталей в составе оружейного комплекса. Предметные реконструкиии могут служить иенными учебными пособиями при чтении лекционных курсов или проведении семинарских занятий по военной истории кочевых народов Центрально-Азиатского историкокультурного региона, в ходе учебного прочесса.

Ключевые слова: Южная Сибирь, Центральная Азия, научно-художественные и предметные реконструкции, комплексы вооружения, древние и средневековые кочевники.

Работа выполнена по проекту «Изучение военного дела древних и средневековых народов Южной Сибири и Центральной Азии».

Научная спечиальность: 07.00.00 - исторические науки. 